\title{
Replacing alfalfa hay with triticale hay has minimal effects on lactation performance and nitrogen utilization of dairy cows in a semi-arid region of Mexico
}

\author{
O. I. Santana, ${ }^{1 *}$ J. J. Olmos-Colmenero, ${ }^{2}$ and M. A. Wattiaux ${ }^{1} \dagger$ \\ ${ }^{1}$ Department of Dairy Science, University of Wisconsin-Madison 53706 \\ ${ }^{2}$ Departamento de Ciencias Pecuarias y Agrícolas, Centro Universitario de Los Altos de la Universidad de Guadalajara, Tepatitlán, Jalisco, \\ México 47600
}

\section{ABSTRACT}

In the semi-arid highlands of central Mexico, triticale ( $\times$ Triticosecale L.) is emerging as an alternative, less water-demanding forage crop than alfalfa for dairy cattle. Studies reported here were aimed at evaluating triticale hay $(\mathrm{TH})$ relative to alfalfa hay $(\mathrm{AH})$ for lactating cow performance, apparent digestibility, N partition, and ruminal degradation kinetics of dry matter (DM), crude protein (CP), and neutral detergent fiber (NDF). Study 1 was conducted on a privately owned farm. Four barns were used to conduct 4 replicated $3 \times$ 3 Latin squares ( 1 barn $=1$ square), where each barn included 3 pens (experimental units) receiving 1 of 3 dietary treatments. Each pen had 62 Holstein dairy cows. All diets included a forage-to-concentrate ratio of 42:58 (DM basis), which is typical for intensive dairy farms of the region. Dietary treatments were formulated to replace $\mathrm{AH}$ with $\mathrm{TH}$ on a $\mathrm{CP}$ basis, and included (DM basis) $15.1 \% \mathrm{AH}$ and $0 \% \mathrm{TH}, 9.0 \% \mathrm{AH}$ and $7.4 \% \mathrm{TH}$, and $0 \% \mathrm{AH}$ and $16.4 \% \mathrm{TH}$. Diets were iso-energetic (1.64 Mcal of net energy for lactation/kg of DM) and iso-nitrogenous $(17.9 \% \mathrm{CP})$. Pen-level DM intake and milk production were from all cows in the pen, but pen-level milk composition, apparent digestibility, and $\mathrm{N}$ partitioning were from 8 cows (observational units) randomly selected in each pen. Orthogonal contrasts were used to determine linear and quadratic effects of increasing $\mathrm{TH}$ from 0 to 7.4 , and $16.4 \%$ of dietary DM. Although DM intake was not affected, there was a tendency for CP intake to decline linearly and for NDF intake to increased linearly as $\mathrm{TH}$ replaced $\mathrm{AH}$ in the diet. Milk production declined linearly by $0.077 \mathrm{~kg} / \mathrm{d}$ for each additional percentage unit of $\mathrm{TH}$ in the diet,

\footnotetext{
Received December 28, 2018.

Accepted May 13, 2019.

*Permanent address: INIFAP Campo Experimental Pabellón, Carretera Aguascalientes-Zacatecas Km. 32.5 Pabellón de Arteaga, Aguascalientes, México 20660.

†Corresponding author: wattiaux@wisc.edu
}

which amounted to a $3.5 \%$ decline when TH replaced AH entirely. However, no effect was observed on energycorrected milk production because of a compensatory linear effect of increasing milk fat concentration with the incorporation of $\mathrm{TH}$ in the diet. Total-tract NDF digestibility tended to increase linearly by $18.5 \%$, but no differences were detected for urinary urea- $\mathrm{N}$ excretion and for $\mathrm{N}$ utilization estimated as milk $\mathrm{N} /$ (fecal $\mathrm{N}+$ urinary $\mathrm{N}+$ milk $\mathrm{N})$. Study 2 was an in situ trial conducted to determine the degradation kinetics of $\mathrm{AH}$ and $\mathrm{TH}$ used in study 1. In spite of differences in degradation kinetics parameters for DM, CP, and NDF, only NDF effective ruminal degradation tended to be greater for $\mathrm{TH}$ than $\mathrm{AH}$. Replacing $\mathrm{AH}$ with $\mathrm{TH}$ at the level typically found in intensive dairy farms of the semi-arid regions of Mexico had minimal effects on milk production and $\mathrm{N}$ utilization.

Key words: forage protein, forage fiber, tropical dairy

\section{INTRODUCTION}

Improvements of dairy systems over the last half-century have allowed considerable reduction in resource use per unit of milk supply in developed countries (Capper et al., 2009). However, in developing and mostly tropical countries, $41 \%$ of milk is produced by low-yielding cows in smallholder farms, and international agencies have promoted sustainable intensification to close the yield gap and strengthen food security of the rapidly increasing population in these regions of the world (Herrero et al., 2013). In Mexico, specialized and largescale dairy farms contribute $50 \%$ of the national milk supply (SIAP, 2018). Those farms are mostly located in arid and semi-arid environments of Northern and Central Mexico where water shortage limits production of corn and alfalfa for silage making (Quiroga Garza and Faz Contreras, 2008). Alfalfa is considered a forage protein source that complements low-protein but high-energy (starch) corn silage in the diet of lactating cows (Dhiman and Satter, 1997). Nonetheless, alfalfa is 
water demanding and its irrigation has been associated with depletion of groundwater (Quiroga Garza and Faz Contreras, 2008). Hence, water scarcity has driven farmers to purchase high-quality alfalfa hay $(\mathbf{A H})$ from other regions of Mexico rather than producing it on farm. The importation of $\mathrm{AH}$ and concentrate feed (notably soybean meals) has resulted in undesirable accumulation of nutrients locally (Figueroa et al., 2015; Santana, 2018). Furthermore, fuel consumption associated with the transportation of these feedstuffs increases the milk carbon footprint (Eide, 2002). Thus, interest is increasing in evaluating homegrown production of forage protein with low water-demanding crops. In Mexico, triticale ( $\times$ Triticosecale L.) is typically grown in the fall-winter season as a forage source for dry cows and heifers. Depending on stage of maturity at harvest, triticale can yield from 9.9 to $14.5 \mathrm{t}$ of DM/ ha and contain from 11.0 to $15 \% \mathrm{CP}$ and from 44.5 to $55.5 \%$ NDF (DM basis; Reta et al., 2017). These yields and composition are in contrast to those reported for temperate regions of the world. For example, Nadeau (2007) reported yields ranging from 6.9 to $9.6 \mathrm{t}$ of DM/ ha in Sweden, whereas Coblentz et al. (2018) reported yields of 2.8 to $9.1 \mathrm{t}$ of $\mathrm{DM} /$ ha in Central Wisconsin, when triticale was grown as winter cover crop. The latter authors also reported $\mathrm{CP}$ in the range of 5.9 to $13.7 \%$ and NDF in the range of 49.5 to $58 \%$ (DM basis). Regardless of these regional differences, the cited authors agreed that harvesting triticale at the boot stage of maturity maximizes the yield of digestible nutrients.

Inconsistent results have been reported when incorporating triticale in the diet of lactating dairy cows. Work completed in Canada reported a decline in DMI but no effect on milk production when replacing $50 \%$ of dietary DM as $\mathrm{AH}$ with triticale silage (Khorasani et al., 1993) and the same results were reported from Iran when replacing $14 \%$ of dietary DM as corn silage with triticale silage (Vatandoost et al., 2007). However, these studies used triticale harvested at the dough stage of maturity to feed cows producing less than $30 \mathrm{~kg} / \mathrm{d}$ of milk. In contrast, Harper et al. (2017) reported that replacing (DM basis) 10\% of corn silage with triticale silage harvested at boot stage of maturity in the diet of cows producing more than $40 \mathrm{~kg} / \mathrm{d}$ of milk had no effect on DMI but lowered milk production and $\mathrm{N}$ use efficiency (milk N/N intake). Under the climate conditions of central Wisconsin, Coblentz et al. (2018) suggested that boot stage may be more desirable than soft dough stage at harvest for lactating cows because of nutritional characteristics (particularly as a forage protein source) and harvest management decisions related to seasonal weather conditions for fall planting and spring harvest. Yields and nutritional quality of forage systems may also be altered by growing triticale (and other grasses) in mixtures with legumes as winter crops (Brown et al., 2018). Thus, for intensive dairy farms in the arid and semi-arid environments of Mexico, including triticale in the cropping system at the expense of alfalfa or as a winter crop harvested at boot stage of growth may enhance homegrown forage production, reduce environmental impacts, and facilitate manure nutrient management (Santana, 2018). Hence, in this study we hypothesized that when $\mathrm{AH}$ and triticale hay (TH) have a similar $\mathrm{CP}$ content, replacing the $\mathrm{CP}$ of $\mathrm{AH}$ with $\mathrm{CP}$ from $\mathrm{TH}$ does not affect performance and $\mathrm{N}$ utilization of dairy cows managed under semi-arid conditions. Therefore, our first objective was to evaluate the effects of replacing $\mathrm{CP}$ from $\mathrm{AH}$ with $\mathrm{CP}$ from $\mathrm{TH}$ on cow performance, apparent digestibility, and N partitioning in lactating dairy cows; our second objective was to determine the ruminal degradation kinetics of DM, CP, and NDF of $\mathrm{AH}$ and $\mathrm{TH}$ to help interpret results of the lactation study.

\section{MATERIALS AND METHODS}

The Institutional Animal Care and Use Committee of the University of Wisconsin-Madison approved the experimental protocols of the 2 studies reported here. Study 1 was conducted from March to May 2016 in a privately owned farm in the municipality of San Juan de los Lagos, state of Jalisco, Mexico. Study 2 was conducted in March 2018 at the Dairy Cattle Center of the University of Wisconsin-Madison.

\section{Study 1: Cow Performance, Apparent Digestibility, and $\mathbf{N}$ Balance}

Origin of Dietary Ingredients. Triticale grown for this study did not replace any crops on the farm, but it was homegrown as a winter crop after corn in a field located at $21^{\circ} 23^{\prime} \mathrm{N}$ and $102^{\circ} 21^{\prime} \mathrm{W}$, at an elevation of $1,799 \mathrm{~m}$ above sea level. The variety TCL-08 Bicentenario released by CIMMYT (Texcoco, México) was used because of high yield, regrowth capacity, and steady performance in agronomic studies conducted locally (unpublished data). Triticale was planted on November 16, 2015, using a seeding rate of $125 \mathrm{~kg} / \mathrm{ha}$. Before planting, $206 \mathrm{~kg} / \mathrm{ha}$ of total $\mathrm{N}$ was applied with bovine compost containing $4 \% \mathrm{~N}$ (DM basis) using a full float spreader (model 54, Newton Croush Inc., Griffin, GA). Crop was irrigated weekly to meet $75 \%$ of water requirements based on the evaporation index, and total water received from irrigation was $500 \mathrm{~mm}$. During the growing season the mean, minimum, and maximum daily temperature was 14,4 , and $23^{\circ} \mathrm{C}$, respectively, 
Table 1. Chemical composition of diets

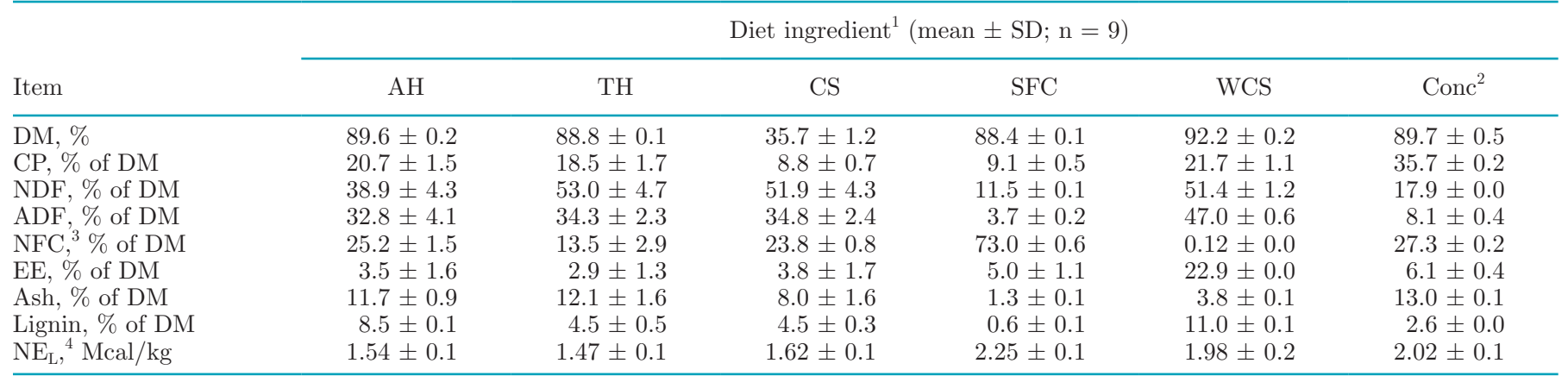

${ }^{1}$ Ingredients: $\mathrm{AH}=$ alfalfa hay; $\mathrm{TH}=$ triticale hay; $\mathrm{CS}=$ corn silage; $\mathrm{SFC}=$ steam-flaked corn; $\mathrm{WCS}=$ whole cottonseed; Conc $=$ concentrate mix.

${ }^{2}$ Concentrate mix (\% of concentrate DM basis): $26.2 \%$ of solvent soybean meal, $16.6 \%$ of canola meal, $9.7 \%$ of expeller soybean meal, $13.4 \%$ of molasses, $14.6 \%$ of dried distillers grains, $7.9 \%$ of bypass fat, $8.0 \%$ of wheat bran, $3.2 \%$ of sodium bicarbonate, and $0.4 \%$ of sodium chloride.

${ }^{3} \mathrm{NFC}$ calculated as NFC $(\%)=100-(\%$ ash $+\% \mathrm{NDF}+\% \mathrm{CP}+\% \mathrm{EE})$. EE $=$ ether extract.

${ }^{4}$ Predicted value from NRC (2001) model using the chemical composition described herewith and overall characteristics of the cows in this study.

and the cumulative precipitation was $37 \mathrm{~mm}$ (INIFAP, 2016), hence total water received was $537 \mathrm{~mm}$. Triticale was cut at d 69 at the boot stage of maturity (earlier than common practice in the region) when the flag leaf was fully emerged, but no seed heads were visible using a flail mower (John Deere 390, Moline, IL). Swaths were wilted before hay-baling on d 79 using a $2000 \mathrm{John}$ Deere 100 equipment. The AH used in this study was purchased as a single large batch of hay bales from the Zacatecas region (192 km north of the study site). As suggested by its composition, AH was likely harvested at an early stage of maturity (Table 1). Before feeding, corn stover, $\mathrm{AH}$, and $\mathrm{TH}$ bales were chopped at length of $12 \mathrm{~mm}$ (HayBuster H-1000, Jamestown, ND). The corn silage had been harvested in the summer of 2015 from the fields where triticale was grown subsequently. Steam-flaked corn grain, whole cottonseed, and concentrate ingredients were from a local feed mill relying on US-based suppliers.

Experimental Design and Diets. Four adjacent open and naturally ventilated barns were included in the study and each barn was used to conduct a Latin square. Each barn comprised 3 pens (experimental units) to which 1 of 3 dietary treatments was allocated randomly. Each pen included 62 Holstein dairy cows (54 primiparous and 8 multiparous, $578 \pm 20 \mathrm{~kg} \mathrm{BW}$, and $120 \pm 34$ DIM; mean \pm SD). The control diet (i.e., the diet with $\mathrm{AH}$ but no $\mathrm{TH}$ ) was formulated with feed ingredients (Table 1) in proportion typically found in intensive dairy farms in the study region (Santana, 2018). Because of the necessity to keep the CP supply of all ingredients constant (except for $\mathrm{AH}$ and $\mathrm{TH}$ ) and to formulate iso-nitrogenous diets, all dietary treatments contained the same proportion of corn silage, steam-flaked corn, whole cottonseed, and concentrates
(Table 2). However, a small percentage of corn stover was included in the control diet as a low NFC, high NDF feed to maintain NFC and NDF content of all diets relatively constant. Diets were iso-energetic and included the characteristically low forage-to-concentrate ratio commonly found in the region ( $42 \%$ forage and $58 \%$ concentrate, DM basis). Thus, experimental diets included (DM basis) either 15.1\% $\mathrm{AH}$ and $0 \%$ TH (AD), 9.0\% AH and $7.4 \% \mathrm{TH}$ (ATD), or $0 \% \mathrm{AH}$ and $16.4 \% \mathrm{TH}$ (TD) and the replacement of CP from $\mathrm{AH}$ with $\mathrm{CP}$ from $\mathrm{TH}$ was 0,42 , and $100 \%$ for the AD, ATD, and TD diet, respectively. Diets were offered twice a day as TMR with 40 and $60 \%$ of daily offering at 0430 and $1630 \mathrm{~h}$, respectively. Refusals were removed and weighed before the afternoon offering. At each offering, a single TMR batch was prepared for each treatment before delivery in 4 pens ( 1 per barn). The weight of TMR to deliver in each pen was calculated to allow $10 \%$ refusals and the actual amount delivered was recorded using a Triotronic EZ $3600 \mathrm{~V}$ weighing system (Trioliet Feeding Technology, Oldenzaal, the Netherlands) calibrated weekly for maximum $2 \%$ error. After each delivery, these data were downloaded on the tracking software of the same manufacturer. Each experimental period comprised $14 \mathrm{~d}$ for adaptation and $7 \mathrm{~d}$ for sampling and data collection. Cows had free access to clean water all the time and they were milked twice daily at 0400 and $1600 \mathrm{~h}$.

Sampling and Data Collection. Dietary ingredients (except corn stover) were sampled weekly, whereas samples of TMR and refusals were collected daily and composited by week. Samples were oven-dried at $55^{\circ} \mathrm{C}$ in a forced-air oven (Oven Precision 845, Chicago, IL) for $48 \mathrm{~h}$. Dried samples were ground to pass a 1-mm screen (Wiley mill, Arthur H. Thomas, Philadelphia, 
Table 2. Ingredients and chemical composition of diets

\begin{tabular}{|c|c|c|c|}
\hline \multirow[b]{2}{*}{ Item } & \multicolumn{3}{|c|}{ Dietary treatment ${ }^{1}$} \\
\hline & $\mathrm{AD}$ & ATD & TD \\
\hline \multicolumn{4}{|c|}{ Ingredient, $\%$ of DM (unless stated) } \\
\hline Alfalfa hay & 15.1 & 9.0 & 0.0 \\
\hline Triticale hay & 0.0 & 7.4 & 16.4 \\
\hline Corn stover & 1.3 & 0.0 & 0.0 \\
\hline Corn silage & 25.9 & 25.9 & 25.9 \\
\hline Steam-flaked corn & 25.8 & 25.8 & 25.8 \\
\hline Whole cottonseed & 5.7 & 5.7 & 5.7 \\
\hline Concentrate $^{2}$ & 25.0 & 25.0 & 25.0 \\
\hline Vitamin and mineral premix ${ }^{3}$ & 1.2 & 1.2 & 1.2 \\
\hline Forage:concentrate ratio & $42: 58$ & $42: 58$ & $42: 58$ \\
\hline \multicolumn{4}{|c|}{ Composition, \% of DM (unless stated) } \\
\hline $\mathrm{CP}$ & 17.9 & 18.0 & 17.8 \\
\hline $\mathrm{RDP}^{4}$ & 10.8 & 11.0 & 10.9 \\
\hline RUP $^{4}$ & 7.1 & 7.0 & 7.0 \\
\hline $\mathrm{NDF}$ & 30.7 & 31.2 & 32.5 \\
\hline $\mathrm{ADF}$ & 17.3 & 17.3 & 17.5 \\
\hline Forage NDF & 20.3 & 20.9 & 22.1 \\
\hline $\mathrm{NFC}^{5}$ & 41.8 & 41.2 & 40.2 \\
\hline $\mathrm{EE}$ & 5.6 & 5.6 & 5.6 \\
\hline $\mathrm{OM}$ & 96.0 & 96.0 & 96.1 \\
\hline $\mathrm{NE}_{\mathrm{L}},{ }^{4} \mathrm{Mcal} / \mathrm{kg}$ & 1.64 & 1.64 & 1.64 \\
\hline Indigestible $\mathrm{ADF}^{6}$ & 9.0 & 8.5 & 8.5 \\
\hline
\end{tabular}

${ }^{1}$ Dietary treatments (DM basis): $\mathrm{AD}=15.1 \%$ alfalfa hay $(\mathrm{AH})$ and $0 \%$ triticale hay $(\mathrm{TH}), \mathrm{ATD}=9.0 \% \mathrm{AH}$ and $7.4 \% \mathrm{TH}$, and $\mathrm{TD}=0 \%$ $\mathrm{AH}$ and $16.4 \% \mathrm{TH}$.

${ }^{2}$ Concentrate mix (\% of concentrate DM basis): $26.2 \%$ of solvent soybean meal, $16.6 \%$ of canola meal, $9.7 \%$ of expeller soybean meal, $13.4 \%$ of molasses, $14.6 \%$ of dried distillers grains, $7.9 \%$ of bypass fat, $8.0 \%$ of wheat bran, $3.2 \%$ of sodium bicarbonate, and $0.4 \%$ of sodium chloride. ${ }^{3}$ Guaranteed analysis (per $\mathrm{kg}$ ): vitamin A, 1,214,000 IU; vitamin $\mathrm{D}_{3}$, 588,000 IU; vitamin E, 19,173 IU; biotin, $143.2 \mathrm{mg}$; Cu, 1,127.4 mg; organic Mn (13\%), $977.1 \mathrm{mg}$; iodine, $134.5 \mathrm{mg}$; Zn + Met chelate, 3,483.8 mg; Zn, 5,015.5 mg; organic Se, 40,646 mg; Se, $130.4 \mathrm{mg}$; Mg, $186.5 \mathrm{mg}$; mineral oil, $10 \mathrm{mg}$; Levucell SC20 (Lallemand, Barcelona, Spain), 6,391 mg; Met, 31,782 mg; monensin, 5,112.8 mg.

${ }^{4}$ Predicted values from NRC (2001) model.

${ }^{5} \mathrm{NFC}$ calculated as $100-(\%$ ash $+\% \mathrm{NDF}+\% \mathrm{CP}+\% \mathrm{EE}) . \mathrm{EE}$ $=$ ether extract.

${ }^{6}$ Indigestible ADF (\% of DM) obtained through $288 \mathrm{~h}$ in situ incubation.

PA). A sub-sample was dried at $105^{\circ} \mathrm{C}$ for $24 \mathrm{~h}$ to determine absolute DM and used subsequently for determination of ash (method 942.05; AOAC International, 2016). Neutral detergent fiber was determined on the $55^{\circ} \mathrm{C}$ dried samples using heat-stable amylase and sodium sulfite in Ankom Fiber Analyzer (Ankom Technology, Macedon, NY). Total N was determined by dry combustion (Leco FP-258, Leco Instruments Inc., St. Joseph, MI) and CP was calculated as N content $\times 6.25$.

Dry matter intake at pen level was determined using daily weight of TMR offered and refused and absolute DM percentages. Values were divided by 62 to express DMI on a per cow basis. Milk production of each cow was recorded for $7 \mathrm{~d}$ consecutively using the farm system software (Dairy Plan C21, GEA Farm Tech- nologies, Naperville, IL) and values were averaged to determine daily milk production on a per cow basis at the pen level. Collection of milk (for milk component yield), urine and feces (for digestibility and $\mathrm{N}$ partition), blood (for serum urea-N), and BW determination was conducted on 8 cows (6 primiparous and 2 multiparous) that were randomly selected from each pen to serve as observational units to determine pen-level data (Tempelman, 2009; Bello et al., 2016). The same 8 cows from each pen were sampled in each period and they were deemed representative of the pen based on the absence of statistical difference (all $P \geq 0.14$ ) in average milk production per cow for the observational units $(\mathrm{n}=8)$ compared with the pen $(\mathrm{n}=62)$.

Individual cow milk samples were collected in 4 consecutive milkings from the evening milking of $\mathrm{d} 16$ to the morning milking of $\mathrm{d} 18$. Samples were preserved with 2-bromo-2-nitropropane-1,2-diol, and analyzed for milk CP, fat, lactose, and MUN using infrared analyzer and for SCC with a Milko Scan FT 6000 (Foss Electric, Hillerød, Denmark) in a private laboratory (Alpura Laboratories, Queretaro, México). Daily milk component yields were calculated by applying the morning and afternoon analytical results to the respective amounts of milk yield estimated using a 60:40 ratio for morning and afternoon milking as observed on this farm (Daniel Ruiz, personal communication). This assumption was inconsequential as statistical inferences for milk component yields and ECM did not change using ratios of $60: 40,45: 55$, or $40: 60$. Although milk production was available for all 62 cows in each pen, milk composition was available only for the 8 observational units in each pen. Thus, pen-level yields of milk components, ECM, and $\mathrm{NE}_{\mathrm{L}}$ output (NRC, 2001) were calculated based on data collected from the 8 observational units in each pen.

Fecal and urine spot samples were collected every $8 \mathrm{~h} \mathrm{(d} 18$ at 1700 h; d 19 at 0100, 0900, and 1700 h; and $\mathrm{d} 20$ at $0100 \mathrm{~h}$ of each period) after restraint of the 8 observational units at the headlock of the feeding alley. Approximately $100 \mathrm{~g}$ of fecal material was grabbed from the rectum of each cow at each time point and added to a single sealed plastic container kept at $4^{\circ} \mathrm{C}$ during sampling and frozen thereafter at $-20^{\circ} \mathrm{C}$ until laboratory analysis. For urine, mid-stream samples were collected from each of the 8 observational units after manual stimulation of the region around the vulva. Then, $10 \mathrm{~mL}$ of urine from each cow were mixed together and stirred manually before $15 \mathrm{~mL}$ was collected and mixed with $60 \mathrm{~mL}$ of $0.072 \mathrm{~N} \mathrm{H}_{2} \mathrm{SO}_{4}$. This pen-level sample was stored at $-20^{\circ} \mathrm{C}$ until laboratory analysis.

A blood sample was collected from the coccygeal vein or artery $4 \mathrm{~h}$ after morning feeding on d 20 on each of 
the 8 observational units. Serum was isolated after the coagulated sample was centrifuged at $1,500 \times g$ for 15 min at room temperature. Samples were kept at $-20^{\circ} \mathrm{C}$ until analysis. Last, on d 16, 17, and 18 at $0900 \mathrm{~h}$, BW was determined using weigh-tapes (Nasco, Ford Atkinson, WI). Heinrichs et al. (2007) found that the prediction of BW from hearth-girth measurements with weight-tape of heifers in the range of 150 to $590 \mathrm{~kg}$ were repeatable and accurate compared with BW obtained with a scale.

Apparent Digestibility. After thawing, fecal samples were dried, ground and analyzed for ash, CP, and NDF as described above for feed samples. Approximately $0.5 \mathrm{~g}$ of fecal and TMR samples were weighed in F-57 Ankom bags (Ankom Technology) and incubated in the ventral sac of 2 rumen-cannulated cows for 288 $\mathrm{h}$ to determine indigestible ADF (iADF) as internal marker to calculate fecal output as iADF intake divided by iADF concentration in feces (Cochran et al., 1986; Huhtanen et al., 1994). Total-tract apparent digestibility of $\mathrm{OM}, \mathrm{CP}$ and NDF was determined from amount of pen-level nutrient in fecal excretion and pen-level daily nutrient intake. Caution in interpreting digestibility values is warranted as the calculations assumed that the DMI of the pen was a valid estimate of the DMI of the 8 observational units.

Urinary $N$ and $N$ Partition. After thawing, urine samples were filtered through Whatman No. 1 filter paper (GE Healthcare, Chicago, IL). Nitrogen content of urine samples was determined using dry combustion (Leco FP-258, Leco Instruments Inc.). Urinary urea-N was determined using the enzymatic reaction described by Fawcett and Scott (1960) in which urea is converted into ammonia by a urease enzyme at concentration of 4,000 IU (Urease Type III, Sigma Aldrich, St. Louis, $\mathrm{MO})$. Urinary creatinine concentration was determined using a commercial kit (Creatinine-J, SpinReact, Girona, Spain), which was based on the colorimetric reaction between creatinine and sodium picrate. Concentration of creatinine was determined by difference of absorbance at $492 \mathrm{~nm}$ at 30 and $90 \mathrm{~s}$ in a spectrophotometer (Genesys 10S, Thermo Scientific, Madison, WI). Creatinine concentration was used as an internal marker to determine urine volume excretion assuming a daily secretion of $29.0 \mathrm{mg} / \mathrm{kg}$ of BW (Valadares et al., 1999). Although this technique was first developed with cow as the experimental unit, Barros et al. (2019) applied it successfully to determine pen-level urine volume and urinary $\mathrm{N}$ excretion. Two ratios were used to assess the relative partitioning of intake $\mathrm{N}$ into fecal $\mathrm{N}$, urinary $\mathrm{N}$, and milk $\mathrm{N}$. These ratios were milk $\mathrm{N}$ divided by $\mathrm{N}$ output in the 3 measured $\mathrm{N}$ pools (i.e., fecal $\mathrm{N}$, urinary $\mathrm{N}$, and milk $\mathrm{N}$ ) and urinary $\mathrm{N}$ divided by fecal $\mathrm{N}$.

\section{Study 2: In Situ Degradation Kinetics of $\mathrm{AH}$ and $\mathrm{TH}$}

Dried and ground samples of $\mathrm{AH}$ and $\mathrm{TH}$ used in study 1 were shipped from Mexico to Madison, Wisconsin. Two rumen-cannulated Holstein cows (700 \pm $15 \mathrm{~kg}$ of BW and $115 \pm 10$ DIM) housed in tiestalls were used for the in situ procedure. Once per day cows were offered a TMR containing (on DM basis): $44.5 \%$ alfalfa silage, $26.8 \%$ corn silage, $10.7 \%$ alfalfa hay, $6.5 \%$ straw, and $11.5 \%$ concentrate mix. Approximately $4.5 \mathrm{~g}$ of sample was weighed into $\mathrm{N}$-free polyester bags $(10 \times$ $20 \mathrm{~cm}$ ) with a pore size of $50 \mu \mathrm{m}$ (R1020, Ankom Technology). Duplicate bags were introduced in the ventral rumen of each cow sequentially and all bags were removed simultaneously to obtain incubation times of $96,72,48,36,24,12,9,6$, and $3 \mathrm{~h}$. The 0 -h bags were soaked for $30 \mathrm{~min}$ in tap water initially at $37^{\circ} \mathrm{C}$. After removal from the rumen, all bags (including 0-h bags) were submerged in cold tap water at $4^{\circ} \mathrm{C}$ for $10 \mathrm{~min}$. Bags were washed in a washing machine for two 12-min rinse cycles and refrigerated overnight before removal of microbial $\mathrm{N}$ using the technique described by Maxin et al. (2013), in which bags were pummeled in a stomacher (Stomacher 400 Lab Blender, Seward Medical, London, UK) for $7 \mathrm{~min}$ in cold $0.9 \%$ saline. Then, bags were oven-dried at $55^{\circ} \mathrm{C}$ for $48 \mathrm{~h}$ and weighed for residual DM content. Residual material was removed from the bags and stored at room temperature until further analysis. Neutral detergent fiber was determined on approximately $0.5 \mathrm{~g}$ of dried residue weighed in F-57 bags designed for Ankom fiber analyzer (Ankom Technology) using heat-stable $\alpha$-amylase and sodium sulfite. Nitrogen was determined by dry combustion (Leco FP258, Leco Instruments Inc.) with CP content calculated as $\mathrm{N} \times 6.25$. The NLIN procedure of SAS (version 9.4, SAS Institute Inc., Cary, NC) was used to fit residual DM, CP, and NDF data to a first-order exponential model modified from Mertens and Loften (1980):

$$
R(t)=100-\left[a+b\left(1-e^{-k_{d}(t-l a g)}\right)+c\right],
$$

where $R(t)=$ residual at time $t(t=1$ to 10$), a(\%)$ $=$ fraction washed from the bag at time $0, b(\%)=$ potentially degradable fraction, $c(\%)=$ undegradable fraction, $k_{d}\left(\mathrm{~h}^{-1}\right)=$ first-order rate of degradation of fraction $b$, and $\operatorname{lag}(\mathrm{h})=$ lag time before degradation of the $b$ fraction begins. The lag time was removed from the model for CP as preliminary analysis showed that it was essentially zero. Equation [2] was used to calculate the effective rumen degradability (ERD) according to Ørskov and McDonald (1979):

$$
\mathrm{ERD}=a+b\left(k_{d} / k_{d}+k_{p}\right),
$$


where $a, b$, and $k_{d}$ are as described in Equation [1] and $k_{p}$ is an assumed ruminal passage rate. Data of study 1 were entered in the NRC (2001), which predicted $k_{p}$ of 5.05 and $4.39 \mathrm{~h}^{-1}$ for $\mathrm{AH}$ and $\mathrm{TH}$, respectively. The $k_{p}$ of NDF was assumed to be $37 \%$ lower than for DM (Lopes et al., 2015) and the $k_{p}$ of CP was set at either the $k_{p}$ for DM or $8.0 \mathrm{~h}^{-1}$ (Krieg et al., 2018).

\section{Statistical Analysis}

For study 1, data were analyzed with Proc MIXED of SAS (SAS Institute Inc.) and the following model:

$$
Y_{i j k l}=\mu+S q_{i}+\operatorname{Pen}(S q)_{i j}+\operatorname{Per}_{k}+\operatorname{Trt}_{l}+E_{i j k l},
$$

where $Y_{i j k l}$ was the dependent variable, $\mu$ was the overall mean, $S q_{i}$ was the effect of $i$ square (i.e., barn), $\operatorname{Pen}(S q)_{i j}$ was the effect of pen $j$ within square $i, P e r_{k}$ was the effect of period $k, \operatorname{Tr}_{l}$ was the effect of treatment $l$, and $E_{i j k l}$ was the residual error. Treatment was considered a fixed effect, whereas period and pen within square were considered random effects. To test the effect of increasing $\mathrm{TH}$ in the diet, linear and quadratic orthogonal contrasts were constructed with coefficients adjusted for the slight unequal spacing of TH in the experimental diets (Proc IML, SAS Institute Inc.). Values reported were least squares means. Only one variable showed a quadratic response (see details below). Hence, for each response variable exhibiting significant effect $(P \leq 0.05)$ or tendency $(0.05<P \leq 0.10)$ the slope of the linear regression was estimated and the percentage change when $\mathrm{TH}$ replaced $\mathrm{AH}$ entirely in the diet was calculated to gauge the magnitude of the effect. Data of study 2 were analyzed as a randomized complete block design using Proc GLM of SAS (SAS Institute Inc.). The model used was

$$
Y_{i j}=\mu+C_{i}+F_{j}+E_{i j},
$$

where $Y_{i j}$ was the predicted value for the parameters $a$, $b, c, k_{d}, l$, and ERD; $\mu$ was the overall mean, $C_{i}$ was the fixed effect of cow $i, F_{j}$ was the fixed effect of forage $j$, and $E_{i j}$ was the residual error. Significance and tendencies were declared as described for study 1 .

\section{RESULTS AND DISCUSSION}

\section{Study 1: Triticale Yield, Cow Performance, Nutrient Digestibility, and N Partition}

Triticale Yield and Estimated TMR Cost. In this study, triticale harvested at the boot stage yielded $5.7 \mathrm{t}$ of $\mathrm{DM} / \mathrm{ha}$, which is more than twice the yield reported in Central Wisconsin by Coblentz et al. (2018) when harvested at the same stage of maturity, but $58 \%$ lower than triticale harvested at dough stage in the semi-arid regions of Mexico (Reta et al., 2017). Future research in these regions should determine whether harvesting at an early stage of maturity may stimulate regrowth sufficiently for a second cut and thus enhance the overall nutrient yield compared with a single harvest at the dough stage of maturity. Under the conditions of this study, we estimated on-farm production costs for TH of $\$ 0.08 / \mathrm{kg}$ of DM compared with $\$ 0.18 / \mathrm{kg}$ of DM for the purchased AH. In addition, TMR cost decreased noticeably from $\$ 8.1$ to $\$ 7.9$ and $\$ 7.7 /$ cow per day for $\mathrm{AD}, \mathrm{ATD}$, and TD, respectively.

Ingredients and Dietary Composition. Although the intent was for $\mathrm{AH}$ and $\mathrm{TH}$ to have the same content of CP to allow for equivalency between the rate of substitution of experimental forages in the diets on a DM basis and a CP basis, AH had slightly greater CP content than TH (20.7 vs. $18.5 \%$ DM basis; Table 1 ). On a DM basis, TH contained 14.1 percentage units more NDF (53.0 vs. $38.9 \%$ ) but 11.7 percentage units less NFC (13.5 vs. $25.2 \%$ ) than $\mathrm{AH}$, which contributed to a lower $\mathrm{NE}_{\mathrm{L}}$ content in the former compared with the latter (1.47 vs. $1.54 \mathrm{Mcal} / \mathrm{kg}$ of DM). The strategy used in ration formulation met our objective of feeding isonitrogenous and iso-energetic diets with similar chemical composition. However, there was a slight increase in forage NDF and NDF contents as $\mathrm{TH}$ replaced $\mathrm{AH}$ in the diets (Table 2). As our control diet was typical for commercial dairy farms of the region, dietary $\mathrm{CP}$ was elevated and $82.1 \%$ of dietary $\mathrm{CP}$ was from the ingredients that remained constant, whereas $17.9 \%$ of dietary $\mathrm{CP}$ was from the experimental forages. Moving across diets from $\mathrm{AD}$ to $\mathrm{ATD}$, and $\mathrm{TD}$, the contribution of $\mathrm{AH}$ to dietary CP decreased from 17.5 to 10.4 , and $0 \%$, whereas the contribution of TH to dietary $\mathrm{CP}$ increased from 0 to 7.6 , and $17.1 \%$, respectively.

Intake. Although DMI was not affected by dietary treatments, intake of $\mathrm{CP}$ tended to decline linearly $(P$ $=0.09)$ by $7 \mathrm{~g} / \mathrm{d}$ and the intake of NDF increased linearly $(P=0.03)$ by $15 \mathrm{~g} / \mathrm{d}$ per percentage unit of $\mathrm{TH}$ incorporated in the dietary DM, which corresponded to a $2.6 \%$ decline and a $3.5 \%$ increase in $\mathrm{CP}$ and $\mathrm{NDF}$ intake, respectively, when $\mathrm{TH}$ replaced $\mathrm{AH}$ entirely (Table 3). Using pen BW values based from the 8 observational units, NDF intake as a percentage of BW was estimated to be $1.25 \pm 0.15,1.25 \pm 0.14$, and $1.29 \pm$ $0.11 \%$ (SEM $=0.04$; linear effect $P=0.03$ ), for the AD, ATD, and TD diets, respectively, and thus increased by $3.2 \%$ when $\mathrm{TH}$ replaced $\mathrm{AH}$ entirely. Cows in this study were mainly primiparous, which have a lower NDF intake capacity than cows of greater parity (Flis and Wattiaux, 2005). Nonetheless, under the conditions of this study, cows consumed more NDF than the 1.0 
Table 3. Effects of replacing alfalfa hay with triticale hay in the diet on pen-level performance data

\begin{tabular}{|c|c|c|c|c|c|}
\hline \multirow[b]{2}{*}{ Item } & \multicolumn{3}{|c|}{ Dietary treatment ${ }^{1}$} & \multirow[b]{2}{*}{ SEM } & \multirow{2}{*}{$\frac{P \text {-value }}{\text { Linear }^{2}}$} \\
\hline & $\mathrm{AD}$ & ATD & TD & & \\
\hline \multicolumn{6}{|l|}{ From 62 cows $/$ pen $^{3}$} \\
\hline \multicolumn{6}{|l|}{ Intake } \\
\hline $\mathrm{DM}, \mathrm{kg} / \mathrm{d}$ & 23.5 & 23.1 & 23.0 & 0.72 & 0.18 \\
\hline $\mathrm{OM}, \mathrm{kg} / \mathrm{d}$ & 22.1 & 21.7 & 21.7 & 0.76 & 0.28 \\
\hline $\mathrm{CP}, \mathrm{kg} / \mathrm{d}$ & 4.22 & 4.16 & 4.11 & 0.12 & 0.09 \\
\hline $\mathrm{NDF}, \mathrm{kg} / \mathrm{d}$ & 7.21 & 7.21 & 7.46 & 0.21 & 0.03 \\
\hline Milk yield, kg/d & 37.6 & 36.9 & 36.3 & 0.53 & $<0.01$ \\
\hline Milk yield/DMI & 1.61 & 1.61 & 1.58 & 0.05 & 0.22 \\
\hline \multicolumn{6}{|l|}{ From 8 cows $/$ pen $^{3}$} \\
\hline $\mathrm{BW}, \mathrm{kg}$ & 579 & 578 & 578 & 5.25 & 0.27 \\
\hline Milk $\mathrm{NE}_{\mathrm{L}},{ }^{4} \mathrm{Mcal} / \mathrm{d}$ & 27.5 & 27.6 & 27.3 & 0.70 & 0.54 \\
\hline $\mathrm{ECM},{ }^{5} \mathrm{~kg} / \mathrm{d}$ & 39.7 & 39.9 & 39.5 & 0.52 & 0.62 \\
\hline \multicolumn{6}{|l|}{ Milk composition } \\
\hline Fat, $\%$ & 3.83 & 3.89 & 3.92 & 0.31 & 0.04 \\
\hline $\mathrm{CP},{ }^{6} \%$ & 3.23 & 3.21 & 3.20 & 0.01 & 0.01 \\
\hline Lactose, \% & 4.99 & 4.98 & 4.98 & 0.01 & 0.07 \\
\hline $\mathrm{SCC}, \times 10^{3}$ cells $/ \mathrm{mL}$ & 64.6 & 78.2 & 88.0 & 10.6 & 0.03 \\
\hline MUN, mg/dL & 12.3 & 12.4 & 12.5 & 0.19 & 0.29 \\
\hline \multicolumn{6}{|l|}{ Component yield } \\
\hline Fat, $\mathrm{kg} / \mathrm{d}$ & 1.44 & 1.46 & 1.45 & 0.09 & 0.63 \\
\hline $\mathrm{CP}, \mathrm{kg} / \mathrm{d}$ & 1.22 & 1.22 & 1.19 & 0.02 & 0.07 \\
\hline Lactose, $\mathrm{kg} / \mathrm{d}$ & 1.88 & 1.87 & 1.84 & 0.04 & 0.11 \\
\hline \multicolumn{6}{|c|}{$\begin{array}{l}{ }^{1} \text { Dietary treatments }(\mathrm{DM} \text { basis): } \mathrm{AD}=15.1 \% \text { alfalfa hay }(\mathrm{AH}) \text { and } 0 \% \text { triticale hay }(\mathrm{TH}), \mathrm{ATD}=9.0 \% \mathrm{AH} \\
\text { and } 7.4 \% \mathrm{TH} \text {, and } \mathrm{TD}=0 \% \mathrm{AH} \text { and } 16.4 \% \mathrm{TH} \text {. }\end{array}$} \\
\hline \multicolumn{6}{|c|}{${ }^{2}$ Linear effects associated with increasing $\mathrm{TH}$ in the diet from 0 , to 7.4 and $16.4 \%$ of dietary DM. } \\
\hline \multicolumn{6}{|c|}{$\begin{array}{l}{ }^{3} 62 \text { cows/pen included all cows in the pen; } 8 \text { cows/pen were randomly selected as observational units to repre- } \\
\text { sent the pen for more intensive measures (Bello et al., 2016). }\end{array}$} \\
\hline \multicolumn{6}{|c|}{$\begin{array}{l}{ }^{4} \mathrm{NE}_{\mathrm{L}}(\text { milk energy output })=\text { milk }(\mathrm{kg} / \mathrm{d}) \times[0.0929 \times \text { fat }(\%)+0.0547 \times \mathrm{CP}(\%)+0.0395 \times \text { lactose }(\%)] \\
(\mathrm{NRC}, 2001 \text {, equation } 2-15) .\end{array}$} \\
\hline \multicolumn{6}{|c|}{$\begin{array}{l}{ }^{5} \text { Energy-corrected milk }(\mathrm{kg} / \mathrm{d})=0.3273 \times \text { milk yield }(\mathrm{kg} / \mathrm{d})+12.97 \times \text { fat yield }(\mathrm{kg} / \mathrm{d})+7.21 \times \text { milk CP yield } \\
(\mathrm{kg} / \mathrm{d}) \text {, derived from Tyrrell and Reid }(1965) . \\
{ }^{6} \text { Significant quadratic effect }(P=0.02) .\end{array}$} \\
\hline
\end{tabular}

to $1.1 \%$ of BW suggested as an upper limit of NDF intake at which rumen fill constrains DMI (Mertens, 1997; Allen, 2000; NRC, 2001). More recently, however, Harper et al. (2017) reported NDF intakes in the range of 1.40 to $1.46 \%$ of BW.

Milk Production. Milk production declined linearly $(P<0.01)$ by $77 \mathrm{~g} / \mathrm{d}$ per unit of $\mathrm{TH}$ in dietary $\mathrm{DM}$, which corresponded to a decline of $3.5 \%$ when TH replaced AH entirely (Table 3). These results may be explained in part by the downward pressure on DMI and increase in rumen fill associated with greater intake of NDF. When cows were challenged with high forage NDF diets (25\% of DM) as alfalfa or orchard grass (a cool-season grass) silage as sole forage source, Kammes and Allen (2012a) observed less ruminal fill for the former compared with the latter but no difference in DMI or milk production. Harper et al. (2017) reported no change in DMI, but lower milk production when replacing corn silage with triticale silage $(10 \%$ of dietary DM) in the ration of cows producing more than $40 \mathrm{~kg} / \mathrm{d}$ of milk, and speculated that the substitution of starch for fiber caused a decline in energy supply. This explana- tion does not apply to our results as the main sources of starch were kept constant across experimental diets (Table 2). In another study in which alfalfa silage was replaced with tall fescue silage (approximately $17 \%$ of dietary DM), Bender et al. (2016) reported numerical reductions in both DMI $(2.3 \mathrm{~kg} / \mathrm{d})$ and milk production $(2.6 \mathrm{~kg} / \mathrm{d})$. In our study, milk energy output and ECM were not affected by dietary treatments (Table 3 ). As a reminder, milk production was based on $n=62$ cows per pen, but ECM was based on production and composition data collected from the 8 observation units per pen. A Student $t$-test failed to detect differences between milk production of the 8 observational units and the 62 cows for each pen $\times$ period combination $(\mathrm{n}=36$; mean $\pm \mathrm{SD} ; 37.4 \pm 1.5$ vs. $37.0 \pm 1.2 \mathrm{~kg} / \mathrm{d}$, respectively; $P=0.14$ ). However, we did not have any means to ascertain that milk composition results of the 8 sampling units per pen were generalizable to all 62 cows in the pen.

Concentration and Yield of Milk Components. Milk CP concentration was the only response variable of this study showing a quadratic response $(P=0.02)$ 
combined with a linear effect $(P=0.01)$. These effects were, however, deemed biologically meaningless as the observed range in concentration was 3 hundredths of a percentage unit (Table 3). Milk fat concentration increased linearly $(P=0.04)$, but the magnitude of this effect was limited $(+2.4 \%)$ when $\mathrm{TH}$ replaced $\mathrm{AH}$ entirely. Harper et al. (2017) reported changes in milk fatty acid profile, but fat concentration and yield were unaffected by replacing corn silage with triticale silage ( $10 \%$ of dietary DM) in the ration. No cases of clinical mastitis were observed during the study, average SCC were low $(<100,000$ cell $/ \mathrm{mL})$, and SCC data were normally distributed, all of which indicated excellent udder health. Nevertheless, the greatest change in milk composition of this study was associated with SCC, which increased linearly $(P=0.03)$ at rate of 1,390 cells $/ \mathrm{mL}$ per percentage unit of $\mathrm{TH}$ incorporated in dietary DM, corresponding to a $36.2 \%$ increase in SCC when $\mathrm{TH}$ replaced $\mathrm{AH}$ entirely. Lower SCC in the milk of cows fed $\mathrm{AH}$ compared with grass hay has been associated with anti-oxidative properties of flavonoids in alfalfa (Zhan et al., 2017). Yields of milk fat and milk lactose remained unaffected, but yield of milk CP tended to decrease linearly $(P=0.07)$ at rate of $2 \mathrm{~g} / \mathrm{d}$, per percentage unit of $\mathrm{TH}$ incorporated in dietary DM. The magnitude of this effect amounted to a decline of $2.5 \%$ of milk $\mathrm{CP}$ yield when $\mathrm{TH}$ replaced $\mathrm{AH}$ entirely. Declines in yields of milk true protein $(5.5 \%)$ and lactose $(6.5 \%)$ have been reported by Harper et al. (2017) when $\mathrm{TH}$ replaced $10 \%$ of corn silage in dietary DM.
$B W$. Average BW was almost identical for cows fed each diet (Table 3). Because of the brevity of each experimental period, we did not track BW change by diet, but the initial and final BW of the 8 observational units from each pen $(\mathrm{n}=96)$ was $574 \pm 47$ and $583 \pm$ $50 \mathrm{~kg}$, respectively. Hence, the $8.8 \mathrm{~kg}$ of BW gain over the $63 \mathrm{~d}$ of the experiment equated to an overall ADG of $0.140 \mathrm{~kg} / \mathrm{d}$.

Apparent Digestibility. Total-tract NDF digestibility tended to increase linearly $(P=0.07)$ by 0.35 unit for each additional percentage of $\mathrm{TH}$ in dietary $\mathrm{DM}$, corresponding to an increase of $18.5 \%$ when $\mathrm{TH}$ replaced AH entirely (Table 4). This result was likely associated with a lower lignification of fiber in $\mathrm{TH}$ than AH (Kuoppala et al., 2009). These authors suggested also that faster ruminal passage rate of legumes compared with grasses may decrease total-tract NDF digestibility. Furthermore, our findings agreed with a recent meta-analysis of de Souza et al. (2018) reporting a rate of increase of 0.26 units in total-tract NDF digestibility (\%) for each additional percentage of grasses (wheat straw, orchardgrass silage, and ryegrass silage) in dietary DM. In contrast, Kammes and Allen (2012a) reported lower total-tract NDF digestibility for orchardgrass silage compared with alfalfa silage.

$N$ Partition. Dietary treatments had no effect on daily excretion of fecal $\mathrm{N}$, urinary $\mathrm{N}$, and urinary urea-N, but milk $\mathrm{N}$ decreased linearly by $0.31 \mathrm{~g} / \mathrm{d}$ per percentage of $\mathrm{TH}$ in dietary $\mathrm{DM}$, corresponding to a decrease of $2.6 \%$ when $\mathrm{TH}$ replaced $\mathrm{AH}$ entirely (Table

Table 4. Effects of replacing alfalfa hay with triticale on nutrient digestibility, N partition, and urea - pen level data based on randomly selected observational units $(n=8$ cows per pen)

\begin{tabular}{|c|c|c|c|c|c|}
\hline \multirow[b]{2}{*}{ Item } & \multicolumn{3}{|c|}{ Dietary treatment ${ }^{1}$} & \multirow[b]{2}{*}{ SEM } & \multirow{2}{*}{$\frac{P \text {-value }}{\text { Linear }^{2}}$} \\
\hline & $\mathrm{AD}$ & ATD & $\mathrm{TD}$ & & \\
\hline \multicolumn{6}{|l|}{ Digestibility, \% } \\
\hline $\mathrm{OM}$ & 62.1 & 63.2 & 62.5 & 1.23 & 0.80 \\
\hline $\mathrm{CP}$ & 64.7 & 65.6 & 64.9 & 1.12 & 0.92 \\
\hline $\mathrm{NDF}$ & 31.4 & 34.2 & 37.2 & 2.29 & 0.07 \\
\hline \multicolumn{6}{|l|}{$\mathrm{N}$ partition, $\mathrm{g} / \mathrm{d}$} \\
\hline Fecal N & 240 & 228 & 230 & 11.6 & 0.41 \\
\hline Urinary N & 224 & 233 & 221 & 15.9 & 0.54 \\
\hline Milk N & 191 & 189 & 186 & 3.37 & 0.07 \\
\hline $\mathrm{N}_{\text {output }}{ }^{3}$ & 655 & 650 & 638 & 17.5 & 0.18 \\
\hline \multicolumn{6}{|l|}{ Ratios } \\
\hline Milk N/N output & 0.293 & 0.292 & 0.293 & 0.00 & 0.99 \\
\hline Urinary $\mathrm{N} /$ fecal $\mathrm{N}$ & 0.983 & 1.025 & 0.790 & 0.10 & 0.80 \\
\hline \multicolumn{6}{|l|}{ Urea-N } \\
\hline Serum, mg/dL & 14.7 & 14.6 & 14.3 & 0.93 & 0.82 \\
\hline Excreted in urine, $\mathrm{g} / \mathrm{d}$ & 127 & 134 & 127 & 6.4 & 0.99 \\
\hline
\end{tabular}


4). The 2 ratios used in this study to assess the relative utilization of dietary $\mathrm{N}$ were not affected by dietary treatments. Milk $\mathrm{N}$ divided by $\mathrm{N}$ output (fecal $\mathrm{N}+$ urinary $\mathrm{N}+$ milk $\mathrm{N}$ ) averaged 0.293 , and urinary $\mathrm{N}$ divided by fecal $\mathrm{N}$ averaged 0.933 . These ratios were 0.305 and $0.671,0.324$ and 1.217 , and 0.309 and 0.839 in the study of Harper et al. (2017), Wattiaux and Karg (2004), and Brito and Broderick (2006), respectively.

Although $\mathrm{N}$ intake of the 8 observational units per pen was unknown, $\mathrm{N}$ use efficiency (milk $\mathrm{N} / \mathrm{N}$ intake) calculated with $\mathrm{N}$ intake from the 62 cows in each pen was estimated to be $28.5 \pm 3.28,28.1 \pm 2.91$, and 27.8 $\pm 1.98 \%$ for $\mathrm{AD}$, ATD, and $\mathrm{TD}$, respectively. Under the same assumption that average $\mathrm{N}$ intake of the 8 observational units was a representative sampling of the $\mathrm{N}$ intake of the 62 cows in each pen, we estimated $\mathrm{N}$ balance $(\mathrm{g} / \mathrm{d})$ as $\mathrm{N}$ intake $-($ fecal $\mathrm{N}+$ urinary $\mathrm{N}+$ milk $\mathrm{N}$ ), where milk $\mathrm{N}$ was calculated as milk $\mathrm{CP} / 6.38$ (DePeters and Ferguson, 1992). The estimated N balance averaged $21.4 \pm 67.9,19.3 \pm 78.8$, and $23.3 \pm$ $40.8 \mathrm{~g} / \mathrm{d}$ for AD, ATD, and TD, respectively. Although these averages reflected a positive $\mathrm{N}$ retention in the body, in agreement with the observed positive ADG, the large variation around these means reflected in part the cumulative error associated with measurements of each $\mathrm{N}$ pool.

Deviations from NRC (2001) Model Predictions for Energy and Nitrogen Utilization. Because the forages used in this study were produced under the semi-arid conditions and the performance data were collected during the warmest month of the year, there was in interest in comparing observed performance data to NRC (2001) model predictions (Table 5). Dry matter intake was approximately $1.0 \mathrm{~kg} / \mathrm{d}$ lower than predicted by NRC. Although this difference can be interpreted as evidence of rumen fill limitation, the experimental diets were high in concentrates (Table 2) and cows on this study appeared to consume somewhat more energy than required for maintenance, milk production, and change in BW (with the latter estimated to be $0.59 \mathrm{Mcal} / \mathrm{d}$ of $\mathrm{NE}_{\mathrm{G}}$; Table 5). Intake regulation is complex as signals from the liver (hepatic oxidation) and gut distension (rumen fill) are integrated in various centers of the brain to stimulate or suppress the consumption of food (Mertens, 1997; Allen et al., 2009). Nonetheless, cows produced 2.2, 1.9, and $2.0 \mathrm{~kg} / \mathrm{d}$ less milk compared with $\mathrm{NRC}$-predicted $\mathrm{NE}_{\mathrm{L}}$ allowable milk for the AD, ATD, and TD diet, respectively. Mild heat stress may have excreted downward pressure on both DMI and milk production of cows in this study. To support this contention, we calculated the temperaturehumidity index (THI; Dikmen and Hansen, 2009) using daily temperatures and relative humidity records
Table 5. Cow performance versus NRC (2001) model predictions ${ }^{1}$

\begin{tabular}{|c|c|c|c|}
\hline \multirow[b]{2}{*}{ Item } & \multicolumn{3}{|c|}{ Dietary treatment ${ }^{2}$} \\
\hline & $\mathrm{AD}$ & ATD & $\mathrm{TD}$ \\
\hline \multicolumn{4}{|l|}{ DMI, kg/d } \\
\hline Predicted & 24.3 & 24.2 & 24.1 \\
\hline Observed - predicted & -0.8 & -1.1 & -1.1 \\
\hline \multicolumn{4}{|l|}{$\mathrm{NE}_{\mathrm{L}}, \mathrm{Mcal} / \mathrm{d}$} \\
\hline Supplied & 38.4 & 37.9 & 37.6 \\
\hline Required $^{3}$ & 37.4 & 37.1 & 36.8 \\
\hline Difference & 1.0 & 0.8 & 0.8 \\
\hline \multicolumn{4}{|l|}{ Milk yield, kg/d } \\
\hline $\mathrm{NE}_{\mathrm{L}}$ allowable milk & 39.8 & 38.8 & 38.3 \\
\hline Observed - predicted $^{4}$ & -2.2 & -1.9 & -2.0 \\
\hline MP allowable milk & 45.7 & 44.7 & 44.1 \\
\hline Observed - predicted $^{5}$ & -8.1 & -7.8 & -7.8 \\
\hline
\end{tabular}

${ }^{1}$ NRC (2001) model predictions based on treatment means of milk production, milk composition, BW, and on analyzed feed composition. ${ }^{2}$ Dietary treatments (DM basis): $\mathrm{AD}=15.1 \% \mathrm{AH}$ and $0 \% \mathrm{TH}, \mathrm{ATD}=$ $9.0 \% \mathrm{AH}$ and $7.4 \% \mathrm{TH}$, and $\mathrm{TD}=0 \% \mathrm{AH}$ and $16.4 \% \mathrm{TH}$, where $\mathrm{AH}$ $=$ alfalfa hay and $\mathrm{TH}=$ triticale hay.

${ }^{3}$ Includes the requirement for maintenance, milk production and growth $\left(\mathrm{NE}_{\mathrm{G}}\right)$ calculated according to NRC (2001) and using observed BW, ADG, milk yield, milk composition, and target BW of $650 \mathrm{~kg}$.

${ }^{4}$ Difference between observed milk production and $\mathrm{NRC}$-predicted $\mathrm{NE}_{\mathrm{L}}$ allowable milk.

${ }^{5}$ Difference between observed milk production and NRC-predicted MP allowable milk.

from the closest meteorological station (INIFAP, 2016). Every day of the study daily mean maximum temperature remained above the thermo-neutral zone of $25^{\circ} \mathrm{C}$, and THI averaged 74 (ranging from 69 to 81). Although early studies established 72 as the threshold THI for heat stress (Armstrong, 1994), recent research has suggested that high-producing cows might experience heat stress at THI as low as 68 (Baumgard and Rhoads, 2012). Cows under heat stress decrease DMI (Eastridge et al., 1998), but Baumgard and Rhoads (2012) found that declining DMI only explained 35 to $50 \%$ of milk yield loss in cows under heat stress. Those authors suggested also that less glucose is available to the mammary gland because of preferentially glucose utilization as an energy source in peripheral tissues when cows are under heat stress. Thus, it appears that cows in this study performed somewhat less than predicted by NRC (2001) in part because of mild heat stress.

In addition, NRC (2001) predicted also a large excess of MP for our experimental diets (Table 5). Our results agreed with those of Olmos Colmenero and Broderick (2006) when using a ration with the same CP content as in this study for both MUN (12.4 vs. $13.0 \mathrm{mg} / \mathrm{dL}$, respectively) and urinary $\mathrm{N}$ excretion (226 vs. $213 \mathrm{~g} / \mathrm{d}$, respectively). However, our values differed substantially than those of Olmos Colmenero and Broderick (2006) for serum urea-N (14.5 vs. $21.6 \mathrm{mg} / \mathrm{dL}$, respectively) 
and for urinary urea-N excretion (129 vs. $174 \mathrm{~g} / \mathrm{d}$ ). These discrepancies may be explained in part by parity; cows were essentially primiparous in our study but multiparous in Olmos Colmenero and Broderick (2006). Although Flis and Wattiaux (2005) did not report urinary urea-N excretion, these authors showed that when fed diets averaging 17.8\% CP (DM basis), primiparous cows excreted $70 \mathrm{~g} / \mathrm{d}$ less urinary $\mathrm{N}$ than multiparous cows (173 vs. $243 \mathrm{~g} / \mathrm{d}$, respectively). Thus, the low urinary urea-N excretion observed in our study may reflect a productive use of predicted excess MP (most likely in the form of $\mathrm{N}$ retention in the body) rather than an excess $\mathrm{N}$ lost in the urine.

\section{Study 2: In Situ Degradation Kinetics}

Degradation kinetics reported here were obtained using material ground through a $1-\mathrm{mm}$ screen in contrast to the NRC (2001) recommendation of a 2-mm screen for in situ studies. Residual DM, CP, and NDF of AH and $\mathrm{TH}$ at each incubation time and model predicted degradation curves are in Figure 1, whereas model predicted kinetic parameters and ERD are in Table 6. For DM, the $a$ and $b$ fractions did not differ, but there was a tendency $(P=0.10)$ for greater $c$ fraction and faster rate of degradation of the $b$ fraction (0.12 vs. $\left.0.06 \mathrm{~h}^{-1}, P=0.05\right)$ for AH than TH; however, the ERD of DM was similar for $\mathrm{AH}$ and $\mathrm{TH}$. For CP degradation kinetics, the $a$ fraction was 20.3 percentage units greater, but the $b$ and the $c$ fractions were 19.1 and 1.2 percentage units lower, respectively, for $\mathrm{TH}$ compared with AH. There was no difference in the rate of degradation of the $b$ fraction and the ERD whether the assumed rate of passage was that of the DM or a value of $8 \% \mathrm{~h}^{-1}$, as suggested by Krieg et al. (2018). Thus, these data suggested similar behavior of the CP and thus similar estimates of rumen degradable protein and rumen undegradable protein for $\mathrm{AH}$ and TH. For NDF, there was no difference between $\mathrm{AH}$ and $\mathrm{TH}$ for the $a$ fraction, which accounts for the loss of fiber particles lost from the washed, but nonincubated bags, and possibly from soluble but indigestible phenolic compounds (Nasrollahi et al., 2015). However, the $b$ fraction, which comprises the potentially degradable NDF, was 20 percentage units greater for $\mathrm{TH}$ than $\mathrm{AH}$ (70 vs. $50 \%, P<$ 0.01). In contrast, the $c$ fraction, which is the asymptotic estimate of undigestible NDF, was 27.8 percentage units lower for TH than AH (15.1 vs. $42.9 \%, P=0.06$; see also Figure 1). Furthermore, the rate of degradation of the potentially degradable NDF was faster for $\mathrm{AH}$ than TH (0.08 vs. $\left.0.05 \mathrm{~h}^{-1} ; P=0.02\right)$ and the lag time was lower for $\mathrm{AH}$ than $\mathrm{TH}(P<0.01)$. Slower rates of degradation for the cell wall of grasses compared with legumes has been associated with higher content
Table 6. In situ degradation kinetics parameters ${ }^{1}$ and effective ruminal degradability (ERD) of alfalfa hay $(\mathrm{AH})$ and triticale hay $(\mathrm{TH})$

\begin{tabular}{lccrr}
\hline Item & Alfalfa hay & Triticale hay & SEM & $P$-value \\
\hline $\mathrm{DM}$ & & & & \\
$a, \%$ of DM & 45.0 & 46.6 & 2.17 & 0.70 \\
$b, \%$ of DM & 35.0 & 40.2 & 2.39 & 0.46 \\
$c, \%$ of DM & 20.0 & 13.1 & 2.07 & 0.10 \\
$k_{d}$ of $b, \mathrm{~h}^{-1}$ & 0.12 & 0.06 & 0.02 & 0.05 \\
Lag, $\mathrm{h}$ & 2.9 & 4.2 & 0.48 & 0.32 \\
$\mathrm{ERD},{ }^{2} \%$ of DM & 69.5 & 67.9 & 0.90 & 0.68 \\
$\mathrm{CP}$ & & & & \\
$a, \%$ of $\mathrm{CP}$ & 40.3 & 60.6 & 5.87 & $<0.01$ \\
$b, \%$ of $\mathrm{CP}$ & 52.7 & 33.6 & 5.52 & $<0.01$ \\
$c, \%$ of $\mathrm{CP}$ & 7.0 & 5.8 & 0.36 & 0.03 \\
$k_{d}$ of $b, \mathrm{~h}^{-1}$ & 0.16 & 0.10 & 0.02 & 0.14 \\
$\mathrm{ERD},{ }^{2} \%$ of CP & 80.5 & 83.4 & 0.88 & 0.16 \\
$\mathrm{ERD},{ }^{3} \%$ of CP & 75.8 & 79.6 & 1.13 & 0.16 \\
$\mathrm{NDF}$ & & & & \\
$a, \%$ of NDF & 7.1 & 14.9 & 2.40 & 0.19 \\
$b, \%$ of NDF & 50.0 & 70.0 & 5.77 & $<0.01$ \\
$c, \%$ of NDF & 42.9 & 15.1 & 8.09 & 0.06 \\
$k_{d}$ of $b, \mathrm{~h}^{-1}$ & 0.08 & 0.05 & 0.01 & 0.02 \\
Lag, h & 0.28 & 2.68 & 0.70 & $<0.01$ \\
ERD, ${ }^{4} \%$ of NDF & 43.0 & 56.8 & 4.03 & 0.07 \\
\hline
\end{tabular}

${ }^{1}$ Parameters: $a$ is the washable fraction at time $0 \mathrm{~h}$ of incubation; $b$ is the potential degradable fraction; $c$ is the asymptotic estimate of the undegradable fraction, $k_{d}$ of $b$ is the first-order rate of degradation of fraction $b$, and lag is the lag time before fraction $b$ starts to degrade in the rumen.

${ }^{2}$ Assuming rate of passage of 5.13 and $4.89 \% \mathrm{~h}^{-1}$ for $\mathrm{AH}$ and $\mathrm{TH}$, respectively (NRC, 2001).

${ }^{3}$ Assuming CP rate of passage of $8.0 \% \mathrm{~h}^{-1}$ (Krieg et al., 2018) for $\mathrm{AH}$ and $\mathrm{TH}$.

${ }^{4}$ Assuming NDF rate of passage of 3.23 and $3.03 \% \mathrm{~h}^{-1}$ for $\mathrm{AH}$ and $\mathrm{TH}$, respectively, which was $37 \%$ lower than the rate of passage of DM (Lopes et al., 2015).

of slow-to-degrade heteroxylans in the former compared with the latter (Bourquin and Fahey, 1994). Using an assumed rate of passage 37\% lower for NDF than for DM (Lopes et al., 2015), that is 3.23 and $3.03 \% \mathrm{~h}^{-1}$ for $\mathrm{AH}$ and $\mathrm{TH}$, respectively, the ERD of NDF tended to be 13.8 percentage units greater for $\mathrm{TH}$ than $\mathrm{AH}$ (43.0 vs. $56.8 \% ; P=0.07$ ). This difference likely contributed to the greater total-tract NDF digestibility for the TD compared with the AD reported in Table 4 and agreed with findings suggesting faster passage rate but lower fiber digestibility for legumes compared with grasses (Kuoppala et al., 2009). Furthermore, the greater level of effective fiber for the cool-season grass compared with the legume reported by Kammes and Allen (2012b) may have contributed to the increase in milk fat percentage observed in this study with increasing $\mathrm{TH}$ in the diet (Table 3).

\section{CONCLUSIONS}

At low inclusion rates, triticale harvested at boot stage of maturity provided a highly digestible source of fiber. Under the conditions of this study, replacing 

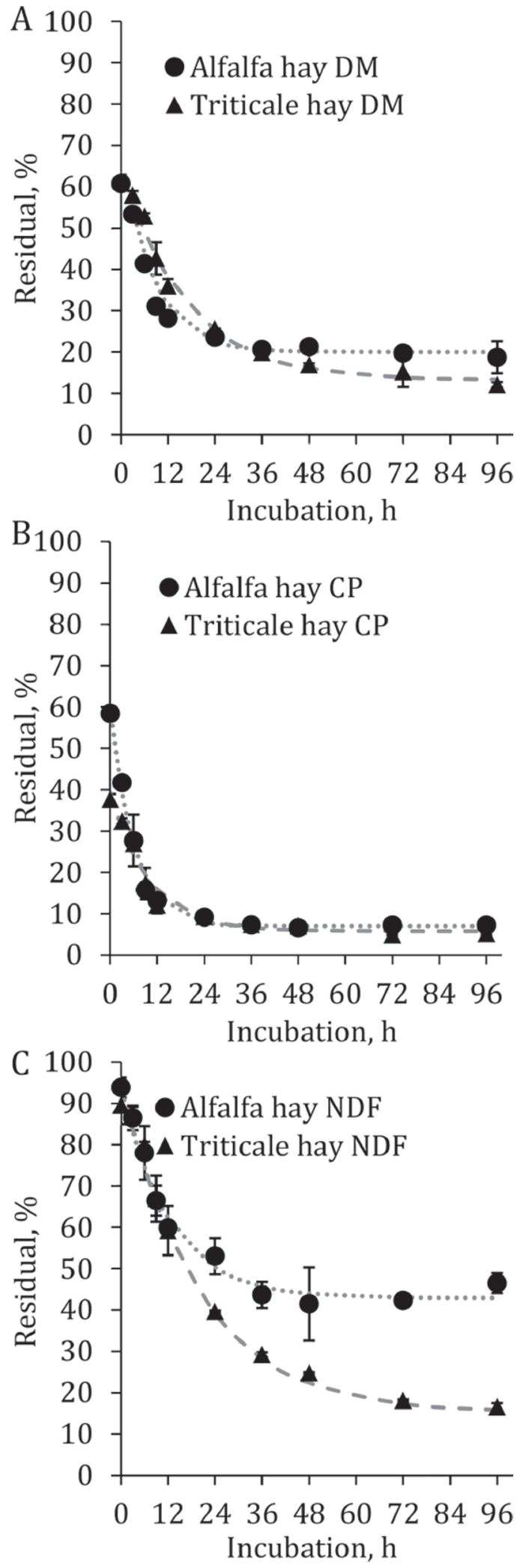

Figure 1. Residual DM (A), CP (B), and NDF (C) of alfalfa hay ( ) and triticale hay $(\mathbf{\Lambda})$, at each in situ incubation time. Dotted and hatched lines are model-predicted degradation curves; vertical bars are $1 \mathrm{SD}$ on each side of the LSM $(\mathrm{n}=4)$.
$15.1 \%$ of $\mathrm{AH}$ with $16.4 \%$ of $\mathrm{TH}$ on $\mathrm{DM}$ basis reduced milk production by $3.5 \%$ but had no effect on ECM. Furthermore, our results suggested that replacing dietary $\mathrm{CP}$ from $\mathrm{AH}$ with dietary $\mathrm{CP}$ from $\mathrm{TH}$ had no effects on $\mathrm{N}$ utilization. Given that this study was designed in the broad context of creating cropping system that are less water-demanding and contribute to reducing whole-farm $\mathrm{N}$ balance of intensive dairy farms of the semi-arid regions of Mexico, we concluded that the intensification of triticale production through earlier harvesting (and double-cropping) may save water resources, enhance homegrown forage production, and may free these farms from their dependence on purchased alfalfa hay from other regions of Mexico. Replacing purchased $\mathrm{AH}$ with homegrown $\mathrm{TH}$ in the diet had minimal effects on performance and dietary $\mathrm{N}$ utilization of lactating dairy cows. Additionally, the substantially lower cost of on-farm production of $\mathrm{TH}$ compared with the purchased price of $\mathrm{AH}$ suggested economic benefits of replacing $\mathrm{AH}$ with $\mathrm{TH}$ in the diet.

\section{ACKNOWLEDGMENTS}

The authors are grateful to PROAN (Jalisco, Mexico) for allowing access to their facilities and personnel to conduct study 1, as well as CONACYT (Consejo Nacional de Ciencia y Tecnología, Mexico City, Mexico) and INIFAP (Instituto Nacional de Investigaciones Forestales, Agrícolas y Pecuarias, Mexico City, Mexico) for scholarship support. In addition, authors are grateful for laboratory support from Universidad de Guadalajara (Campus de Los Altos, Tepatitlan, Jalisco, Mexico), Sandy Bertics and the personnel of the University of Wisconsin Dairy Cattle Center for study 2.

\section{REFERENCES}

Allen, M. S. 2000. Effects of diet on short-term regulation of feed intake by lactating dairy cattle. J. Dairy Sci. 83:1598-1624. https:// doi.org/10.3168/jds.S0022-0302(00)75030-2.

Allen, M. S., B. J. Bradford, and M. Oba. 2009. Board-Invited Review: The hepatic oxidation theory of the control of feed intake and its application to ruminants. J. Anim. Sci. 87:3317-3334. https://doi .org/10.2527/jas.2009-1779.

AOAC International. 2016. Official Methods of Analysis. 20th ed. Association of Official Analytical Chemists, Washington, DC.

Armstrong, D. V. 1994. Heat stress interaction with shade and cooling. J. Dairy Sci. 77:2044-2050. https://doi.org/10.3168/jds.S0022 -0302(94)77149-6.

Barros, T., K. F. Reed, J. J. Olmos Colmenero, and M. A. Wattiaux. 2019. Short Communication: Milk urea nitrogen as predictor of urinary nitrogen and urea nitrogen excretions of late-lactation dairy cows fed nitrogen-limiting diets. J. Dairy Sci. 102:1601-1607. https://doi.org/10.3168/jds.2018-14551.

Baumgard, L. H., and R. P. Rhoads. 2012. Ruminant Nutrition Symposium: Ruminant production and metabolic responses to heat stress. J. Anim. Sci. 90:1855-1865. https://doi.org/10.2527/jas .2011-4675. 
Bello, N. M., M. Kramer, R. J. Tempelman, W. W. Stroup, N. R. St-Pierre, B. A. Craig, L. J. Young, and E. E. Gbur. 2016. Short communication: On recognizing the proper experimental unit in animal studies in the dairy sciences. J. Dairy Sci. 99:8871-8879. https://doi.org/10.3168/jds.2016-11516.

Bender, R. W., F. Lopes, D. E. Cook, and D. K. Combs. 2016. Effects of partial replacement of corn and alfalfa silage with tall fescue hay on total-tract digestibility and lactation performance in dairy cows. J. Dairy Sci. 99:5436-5444. https://doi.org/10.3168/jds.2015 -10222 .

Bourquin, L. D., and G. C. Fahey Jr. 1994. Ruminal digestion and glycosyl linkage patterns of cell wall components from leaf and stem fractions of alfalfa, orchardgrass, and wheat straw. J. Anim. Sci. 72:1362-1374. https://doi.org/10.2527/1994.7251362x.

Brito, A. F., and G. A. Broderick. 2006. Effect of varying dietary ratios of alfalfa silage to corn silage on production and nitrogen utilization in lactating dairy cows. J. Dairy Sci. 89:3924-3938.

Brown, A. N., G. Ferreira, C. L. Teets, W. E. Thomason, and C. D. Teutsch. 2018. Nutritional composition and in vitro digestibility of grass and legume winter (cover) crops. J. Dairy Sci. 101:20372047. https://doi.org/10.3168/jds.2017-13260.

Capper, J. L., R. A. Cady, and D. E. Bauman. 2009. The environmental impact of dairy production: 1944 compared with 2007. J. Anim. Sci. 87:2160-2167. https://doi.org/10.2527/jas.2009-1781.

Coblentz, W. K., M. S. Akins, K. F. Kalscheur, G. E. Brink, and J. S. Cavadini. 2018. Effects of growth stage and growing degree day accumulations on triticale forages: 1 . Dry matter yield, nutritive value, and in vitro dry mater disappearance. J. Dairy Sci. 101:8965-8985. https://doi.org/10.3168/jds.2018-14868.

Cochran, R. C., D. C. Adams, J. D. Wallace, and M. L. Galyean. 1986. Predicting digestibility of different diets with internal markers: Evaluation of four potential markers. J. Anim. Sci. 63:1476-1487. https://doi.org/10.2527/jas1986.6351476x.

de Souza, R. A., R. J. Tempelman, M. S. Allen, W. P. Weiss, J. K. Bernard, and M. J. VandeHaar. 2018. Predicting nutrient digestibility in high-producing dairy cows. J. Dairy Sci. 101:1123-1135. https://doi.org/10.3168/jds.2017-13344.

DePeters, E. J., and J. D. Ferguson. 1992. Nonprotein nitrogen and protein distribution in the milk of cows. J. Dairy Sci. 75:31923209. https://doi.org/10.3168/jds.S0022-0302(92)78085-0.

Dhiman, T. R., and L. D. Satter. 1997. Yield response of dairy cows fed different proportions of alfalfa silage and corn silage. J. Dairy Sci. 80:2069-2082. https://doi.org/10.3168/jds.S0022-0302(97)76152 -6 .

Dikmen, S., and P. J. Hansen. 2009. Is the temperature-humidity index the best indicator of heat stress in lactating dairy cows in a subtropical environment? J. Dairy Sci. 92:109-116. https://doi .org/10.3168/jds.2008-1370.

Eastridge, M. L., H. F. Bucholtz, A. L. Slater, and C. S. Hall. 1998. Nutritional requirements for dairy cattle of the National Research Council versus some commonly used ration software. J. Dairy Sci. 81:3049-3062. https://doi.org/10.3168/jds.S0022-0302(98)75870 -9 .

Eide, M. H. 2002. Life cycle assessment (LCA) of industrial milk production. Int. J. LCA 7:115-126. https://doi.org/10.1007/ BF02978855.

Fawcett, J. K., and J. E. Scott. 1960. A rapid clinical method for the estimation of urea in urine. J. Clin. Pathol. 13:156.

Figueroa, V. U., G. Núñez-Hernández, D. G. Reta-Sánchez, and H. E. Flores-López. 2015. Regional nitrogen balance in the milk-forage production system in the Comarca Lagunera, Mexico. Rev. Mex. Cienc. Pecu. 6:377-392.

Flis, S. A., and M. A. Wattiaux. 2005. Effects of parity and supply of rumen-degraded and undegraded protein on production and nitrogen balance in Holsteins. J. Dairy Sci. 88:2096-2106. https://doi .org/10.3168/jds.S0022-0302(05)72886-1

Harper, M. T., J. Oh, F. Giallongo, G. W. Roth, and A. N. Hristov. 2017. Inclusion of wheat and triticale silage in the diet of lactating dairy cows. J. Dairy Sci. 100:6151-6163. https://doi.org/10.3168/ jds.2017-12553.
Heinrichs, A. J., H. N. Erbs, G. W. Rogers, J. B. Cooper, and C. M. Jones. 2007. Variability in Holstein heifer heart-girth measurements and comparison of prediction equations for live weight. Prev. Vet. Med. 78:333-338. https://doi.org/10.1016/j.prevetmed .2006.11.002.

Herrero, M., D. Grace, J. Njuki, N. Johnson, D. Enahoro, S. Silvestri, and M. C. Rufino. 2013. The roles of livestock in developing countries. Animal 7(Suppl. 1):3-18. https://doi.org/10.1017/ S1751731112001954.

Huhtanen, P., K. Kaustell, and S. Jaakkola. 1994. The use of internal markers to predict total digestibility and duodenal flow of nutrients in cattle given six different diets. Anim. Feed. Sci. Tech. 48:211-227. https://doi.org/10.1016/0377-8401(94)90173-2.

INIFAP. 2016. Instituto Nacional de Investigaciones Forestales, Agrícolas y Pecuarias (INIFAP) National Network of Weather Stations. https://clima.inifap.gob.mx/lnmysr.

Kammes, K. L., and M. S. Allen. 2012a. Nutrient demand interacts with forage family to affect digestion responses in dairy cows. J. Dairy Sci. 95:3269-3287. https://doi.org/10.3168/jds.2011-5021.

Kammes, K. L., and M. S. Allen. 2012b. Rates of particle size reduction and passage rate are faster for legume compared with coolseason grass, resulting in lower rumen fill and less effective fiber. J. Dairy Sci. 95:3288-3297. https://doi.org/10.3168/jds.2011-5022.

Khorasani, G. R., E. K. Okine, J. J. Kennelly, and J. H. Helm. 1993. Effect of whole crop cereal grain silage substituted for alfalfa silage on performance of lactating dairy cows. J. Dairy Sci. 76:35363546. https://doi.org/10.3168/jds.S0022-0302(93)77692-4.

Krieg, J., N. Seifried, H. Steingass, and M. Rodehutscord. 2018. In situ and in vitro evaluation of crude protein degradation and utilisable crude protein content of barley, rye and triticale grains for ruminants. J. Anim. Physiol. Anim. Nutr. (Berl.) 102:452-461. https:/ /doi.org/10.1111/jpn.12767.

Kuoppala, K., S. Ahvenjärvi, M. Rinne, and A. Vanhatalo. 2009. Effects of feeding grass or red clover silage cut at two maturity stages in dairy cows. 2. Dry matter intake and cell wall digestion kinetics. J. Dairy Sci. 92:5634-5644. https://doi.org/10.3168/jds.2009 -2250 .

Lopes, F., D. E. Cook, and D. K. Combs. 2015. Validation of an in vitro model for predicting rumen and total-tract fiber digestibility in dairy cows fed corn silages with different in vitro neutral detergent fiber digestibilities at 2 levels of dry matter intake. J. Dairy Sci. 98:574-585. https://doi.org/10.3168/jds.2014-8661.

Maxin, G., D. R. Ouellet, and H. Lapierre. 2013. Ruminal degradability of dry matter, crude protein, and amino acids in soybean meal, canola meal, corn, and wheat dried distillers grains. J. Dairy Sci. 96:5151-5160. https://doi.org/10.3168/jds.2012-6392.

Mertens, D. R. 1997. Creating a system for meeting the fiber requirements of dairy cows. J. Dairy Sci. 80:1463-1481. https://doi.org/ 10.3168/jds.S0022-0302(97)76075-2.

Mertens, D. R., and J. R. Loften. 1980. The effect of starch on forage fiber digestion kinetics in vitro. J. Dairy Sci. 63:1437-1446. https: //doi.org/10.3168/jds.S0022-0302(80)83101-8.

Nadeau, E. 2007. Effects of plant species, stage of maturity and additive on the feeding value of whole-crop cereal silage. J. Sci. Food Agric. 87:789-801. https://doi.org/10.1002/jsfa.2773.

Nasrollahi, S. M., M. Imani, and Q. Zebeli. 2015. A meta-analysis and meta-regression of the effect of forage particle size, level, source, and preservation method on feed intake, nutrient digestibility, and performance in dairy cows. J. Dairy Sci. 98:8926-8939. https://doi .org/10.3168/jds.2015-9681.

NRC. 2001. Nutrient Requirements of Dairy Cattle. 7th ed. Natl. Acad. Press. Washington, DC.

Olmos Colmenero, J. J., and G. A. Broderick. 2006. Effect of dietary crude protein concentration on milk production and nitrogen utilization in lactating dairy cows. J. Dairy Sci. 89:1704-1712. https:/ /doi.org/10.3168/jds.S0022-0302(06)72238-X.

Ørskov, E. R., and I. McDonald. 1979. The estimation of protein degradability in the rumen from incubation measurements weighted according to rate of passage. J. Agric. Sci. Camb. 92:499-503. https://doi.org/10.1017/S0021859600063048. 
Quiroga Garza, H. M., and R. Faz Contreras. 2008. Increase in water use efficiency by alfalfa with water-limiting irrigations during summer. Terra Latinoam. 26:111-117.

Reta, S. D. G., J. S. Serrato Corona, H. M. Quiroga Garza, A. Gaytan Mascorro, and U. Figueroa-Viramontes. 2017. Alternative crop sequences for increasing the forage potential and water productivity. Rev. Mex. Cienc. Pecu. 8:397-406. https://doi.org/10.22319/rmcp .v8i4.4645.

Santana, O. I. 2018. Impacts of forage source and level in intensive dairy systems: Whole-farm nutrient balance, lactation performance, and feeding behavior. PhD Thesis, Department of Dairy Science. University of Wisconsin-Madison.

SIAP. 2018. Sistema de Información Agroalimentaria y Pesquera. Gobierno Federal México. Accessed Nov. 15, 2018. http://nube.siap.gob .mx/gobmx_publicaciones_siap/pag/2016/Atlas-Agroalimentario -2016 .

Tempelman, R. J. 2009. Invited review: Assessing experimental designs for research conducted on commercial dairies. J. Dairy Sci. 92:1-5. https://doi.org/10.3168/jds.2008-1404.

Tyrrell, H. F., and J. T. Reid. 1965. Prediction of the energy value of cow's milk. J. Dairy Sci. 48:1215-1223. https://doi.org/10.3168/ jds.S0022-0302(65)88430-2.
Valadares, R. F. D., G. A. Broderick, S. C. Valadares, and M. K. Clayton. 1999. Effect of replacing alfalfa silage with high-moisture corn on ruminal protein synthesis estimated from excretion of total purine derivates. J. Dairy Sci. 82:2686-2696. https://doi.org/10 .3168/jds.S0022-0302(99)75525-6.

Vatandost, M., M. D. Mesgaran, R. Valizadeh, and H. N. Moghaddam. 2007. Effect of whole crop silages (triticale or barley) versus corn silage on performance of Holstein lactating dairy cows. J. Anim. Vet. Adv. 6:344-348.

Wattiaux, M. A., and K. L. Karg. 2004. Protein level for alfalfa and corn silage-based diets: II. Nitrogen balance and manure characteristics. J. Dairy Sci. 87:3492-3502. https://doi.org/10.3168/jds .S0022-0302(04)73484-0.

Zhan, J., M. Liu, X. Su, K. Zhan, Ch. Zhang, and G. Zhao. 2017. Effects of alfalfa flavonoids on the production performance, immune system, and ruminal fermentation of dairy cows. Asian-australas. J. Anim. Sci. 30:1416-1424. https://doi.org/10.5713/ajas.16.0579. 